no interruption to the supply. If a fault were to system, the sustained feeding of power into it would probably lead to a serious breakdown and fire, with the risk of a long-maintained interruption of the supply. Occurrences of this nature have taken place during the last few years due, for example, to leakages from transient faults on overhead lines and leakages due to fires resulting from sustained arcing on unprotected apparatus. These risks are uneconomic and should be guarded against by safeguards of the type described in this paper, adequate to protect the network from damage.

\section{New Museum of the University of Colorado}

Prof. T. D. A. Cockerell writes : "When I came to the University of Colorado in 1904, there was no museum. Judge Junius Henderson, a lawyer, but also a very keen amateur naturalist, became honorary develop in an unprotected component of a supply

\section{Archæological Discovery at Sakkara, Egypt}

THE discovery at North Sakkara, forty miles south of Cairo, of a tomb which it is thought may prove to be that of Menes, the first king of the First Dynasty of Egypt (c. 3300 B.c.), is of exceptional interest, both on account of its historical associations, and also in view of the fact that the tomb of this monarch had been thought to have been discovered many years ago by Sir Flinders Petrie at Abydos. The grounds for this tentative attribution of the tomb now found are the hundred or more clay sealings bearing the name 'Aha', generally identified as that of King Menes, and the fact that no other name appears. The discovery was made by Mr. Walter Emery, who has been engaged in excavation on the site for the past three years. Of all the tombs brought to light here up to the present, this is the largest. It contains five chambers. Its roof had fallen in and it had been plundered; but according to the reports in The Times of January 7-8, associated with the skeletal remains of two aged individuals was a large number of antiquities, of which the most important are quantities of stone and alabaster jars, many inscribed with the name of the king. The pottery includes shapes not hitherto recorded in Egypt. In addition to slate palettes there are fragments of funerary furniture, among which are the traditional ivory bull's legs of chairs and parts of a wooden bed similar in design to that already known as belonging to Queen Hetepheres of the Fourth Dynasty. A novel feature of the tomb is the coloured reed matting, which was affixed to the clay walls while they were still wet, forming, it is pointed out, a primitive kind of wall-paper. Many

Museum of Untversity of Colorado

curator of the then insignificant collections. Owing to his energy and enthusiasm, the collections grew, and in course of time Henderson was made professor, and giving up his law, devoted his whole time to the Museum. Until recently, the collections were housed in one wing of a building devoted to instruction, and having become very extensive, were crowded so that it was difficult to find room for anything more. The collection of molluses, in particular, is one of the best in America, and the many fossils include the types of numerous species of insects, shells and plants. The Museum has now moved into a new building, shown herewith. There are fine exhibition galleries for the zoological specimens, for the fossils and minerals, and for the important collections gathered by Earl Morris, representing the work of the ancient inhabitants of south-western North America. It is greatly regretted that Junius Henderson died on November 4, after a very long illness, and was not able to see the fruition of his years of labour in the new building. He has been succeeded by Prof. Hugo Rodeck." of the sealings bear inscriptions in black ink. Mr. Emery proposes to excavate below the adjoining Third Dynasty tombs in the hope that the discovery of the burial places of the king's servants will confirm the tentative attribution of the tomb to Menes.

\section{Recent Acquisitions by the British Museum}

IN the announcement of the additions to the archæological and ethnographical collections of the British Museum (Bloomsbury) during the past month it is stated that the antiquities from Skara Brae, Orkney, which were deposited in the collections on loan in 1933 have now been given to the Museum by the owner, Mr. Walter G. Grant. It will be remembered that this site was excavated by Prof. Gordon Childe, whose careful investigation of this remarkable prehistoric town, or village, revealed a picture of early culture so complete as to constitute on its primitive scale something in the nature of a 'Knossos' of the north. Among other antiquities accruing to the Museum are the remarkable and important collections 